\title{
An Attempt to Determine the Size of Biometric Differences in the Skull of Two Colour Variants of American Mink (Neovison vison)
}

\author{
Un Intento de Determinar la Magnitud de las Diferencias Biométricas del Cráneo \\ de Dos Variedades de Color del Visón Americano (Neovison vison)
}

\author{
Piotr Baranowski "; Katarzyna Pezinska-Kijak"; Lidia Felska-Blaszczyk"; Krzysztof Zuk*; \\ Piotr Nowak*; Joanna Kosecka*; Kamila Oczeretko*; Peter Chukwu* \& Pawel Mazur*
}

\begin{abstract}
BARANOWSKI, P.; PEZINSKA-KIJAK, K.; FELSKA-BLASZCZYK, L.; ZUK, K.; NOWAK, P.; KOSECKA, J.; OCZERETKO, K.; CHUKWU, P. \& MAZUR, P. An attempt to determine the size of biometric differences in the skull of two colour variants of American mink (Neovison vison). Int. J. Morphol., 32(3):895-901, 2014.
\end{abstract}

SUMMARY: This study aimed at answering the question whether production of new colour variants of American mink in mink farms using mutations may entail changes in skull morphology and relationships between the bone elements building it. Analyses were made on the skulls of 56 eight-month-old males and females of two American mink colour variants (standard Brown and mutant Sapphire) from the same farm. Mean values, standard deviations and coefficients of variation were determined for carcass weight, cranial and mandibular weights and 7 dorsal surface, 8 lateral surface and 11 basal surface traits of the skull. The values of 24 cranial and mandibular indices and the values of sexual size dimorphism (SSD), i.e. a coefficient describing differences between sexes, were calculated. It was demonstrated that mutant colour variants of American mink may be a significant source of variation $(\mathrm{P} \leq 0.05$ and $\mathrm{P} \leq 0.01)$ for some traits of skull morphology and relationships between respective bone elements of viscerocranium and neurocranium.

KEY WORDS: Biometry; Neovison vison; Viscerocranium; Neurocranium; Skull.

\section{INTRODUCTION}

American mink (Neovison vison), coming from the American continent to Europe, has turned out to be extraordinarily varied in breeding. The history of its association with man, early days of its breeding, and later the environmental impact of animals escaped from farms or individuals being purposefully set loose or wild/farm mink hybrids have been previously presented in other papers (Shackelford, 1984; Kruska \& Sidorovich, 2003; Kidd et al., 2009; Zalewski \& Bartoszewicz, 2012). When American mink farm breeding was started for the first time in the USA and Canada, mink herds were assembled from wild animals from different geographical regions and, over time, the coat type and the body size were being standardized. A result of repeated cross-breeding was formation of a new type of mink, being far-distant from its wild ancestors. It has been called a standard mink. This type was imported to Europe and gave rise to all mutant colour variants. The result of mutation detection or cross-breeding of mutant variants between each other is formation of colour variants being differently coloured than standard variant. The colour variants obtained differ between each other in vitality, fecundity, resistance to certain diseases, gestation length and number of matings, offspring mortality, or tendency for anomalies, such as - for instance - helical head twisting, but also in size, irrespective of pronounced sexual dimorphism (Sundqvist et al., 1989; Felska-Blaszczyk et al., 2008, 2010; Slaska et al., 2009; Liu et al., 2011).

Morphological studies of wild mink populations have shown significant inter-population differences referring, among others, to the size of respective skull parts (Kruska \& Schreiber, 1999; Sidorovich \& McDonald, 2001; Kruska \& Sidorovich; Tamlin et al., 2009). Owing to these studies, it is also possible to identify wild and farm mink populations, as well as possible hybrids resulting from cross-breeding of the animals which escaped from farms with wild ones. Above all, the brain size is being considered to be a key criterion when defining domestication traits (O'Regan \& Kitchner, 2005). An impulse for the study being presented here was the intention to receive an answer to the question whether production of new colour variants of American mink in mink farms using 
mutations may entail changes in skull morphotype and relationships between the bone elements building it.

\section{MATERIAL AND METHOD}

The study was conducted on the skulls of 56 eightmonth-old males and females of two American mink colour variants from a mink farm situated in north-western Poland (53o40'N, 15o08'E). The first group consisted of Brown (Pastel) variant minks, being a standard variant, whereas the second group of those of the Sapphire (Cerulean) variant which are a double recessive genetic mutation, being formed by combination of the Aleutian (Lutetia) and the Silver Blue (Silverblu) variants. Until slaughter, males and females of the two colour variants were kept under the same maintenance and feeding conditions. After skinning, the carcasses obtained were weighed to the nearest $0.1 \mathrm{~kg}$. Thereafter, mink heads were separated from the trunk and cleaned by removing soft tissues, followed by their maceration at about $100^{\circ} \mathrm{C}$ for 60 minutes. In the next stage, the skulls were bathed in a $30 \%$ hydrogen peroxide solution (Perhydrol@) to make cranial sutures and syndesmoses visible.

Thirty eight skulls were from the Brown (Pastel) variant minks (15 males and 23 females), while 18 belonged to the Sapphire (Cerulean) variant ones (9 males and 9 females). Applying the method adopted by Kruska \& Sidorovich (2003), and supplemented by Baranowski et al. (2013) the following measurements were taken on the skulls: $1 . \mathrm{NAL}=$ Nasal length; 2. $\mathrm{POL}=$ Postorbital length; $3 . \mathrm{NCL}=$ Neurocranium length; 4. $\mathrm{IOC}=$ Interorbital constriction; $5 . \mathrm{POC}=$ Postorbital constriction; $6 . \mathrm{BCB}=$ Brain case breadth; $7 . \mathrm{MAB}=$ Mastoid breadth; 8. FSH= Frontal skull height; $9 . \mathrm{BCH}=$ Brain case height; 10. $\mathrm{CSH}=$ Caudal skull heigh; 11. MAH= Mandible height; 12. MAL= Mandible length; 13. DNL= Dental length; 14. $\mathrm{CAL}=$ Carnassial length; 15. M1L= Molar length; 16 . $\mathrm{CBL}=$ Condylobasal length; $17 . \mathrm{PAL}=$ Palatinal length; 18. $\mathrm{BBL}=$ Brain basis length; 19. MXT= Maxillary tooth; 20. $\mathrm{BRC}=$ Breadth over the canines; 21. INW= Incisor width; 22. $\mathrm{JUB}=$ Jugal (zygomatic) breadth; 23. FMW= Foramen magnum width; 24. FMH= Foramen magnum high; 25. ABL= Auditory bulla length and 26. ABW= Auditory bulla width.

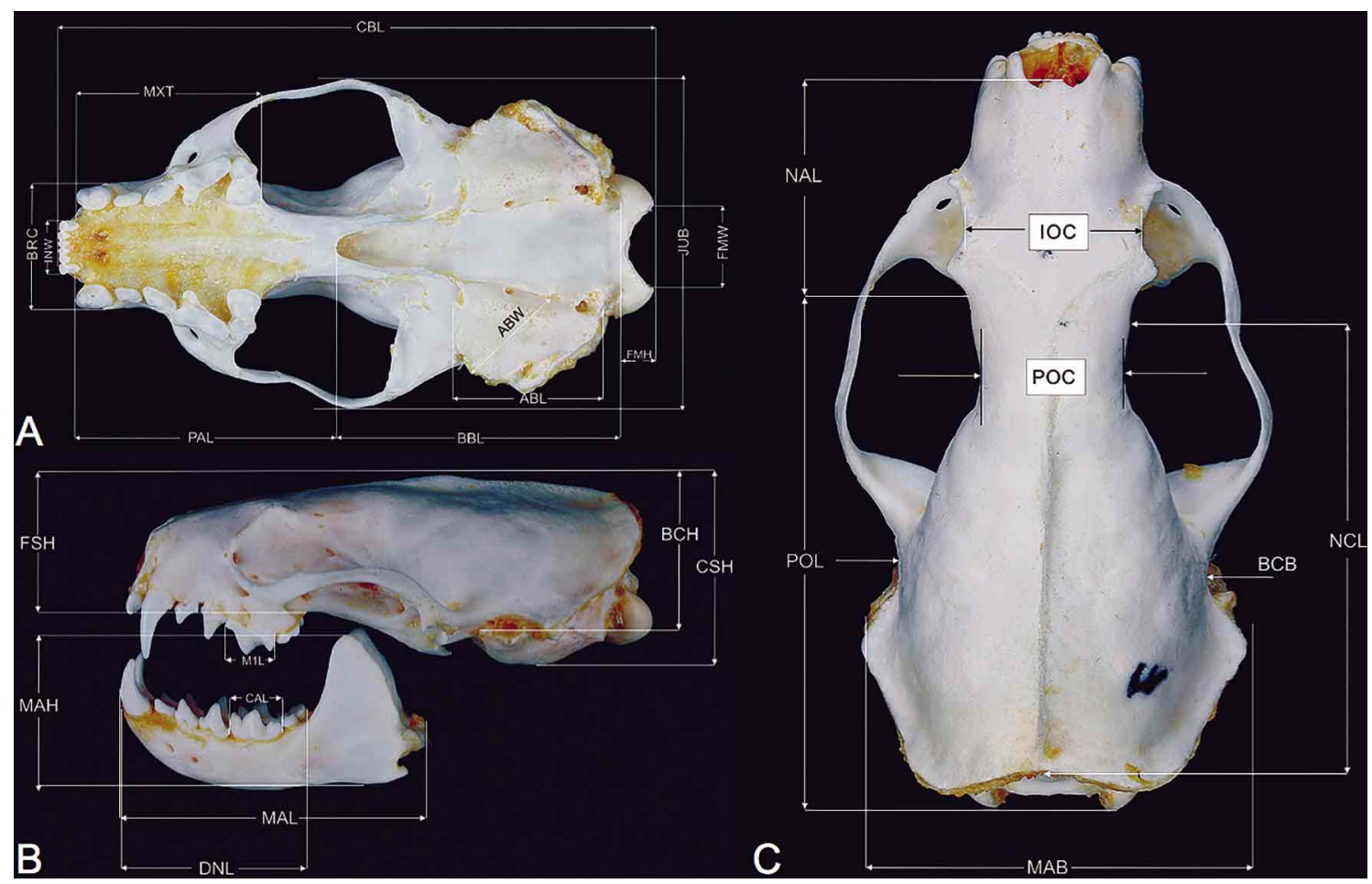

Fig. 1. External measurements of the basal (A), lateral (B) and dorsal (C) parts of mink skulls. 1. NAL= Nasal length; 2. $\mathrm{POL}=$ Postorbital length; 3. NCL= Neurocranium length; 4. IOC= Interorbital constriction; $5 . \mathrm{POC}=$ Postorbital constriction; $6 . \mathrm{BCB}=$ Brain case breadth; $7 . \mathrm{MAB}=$ Mastoid breadth; 8. FSH= Frontal skull height; 9 . $\mathrm{BCH}=\mathrm{Brain}$ case height; $10 . \mathrm{CSH}=$ Caudal skull heigh; $11 . \mathrm{MAH}=$ Mandible height; $12 . \mathrm{MAL}=$ Mandible length; $13 . \mathrm{DNL}=\mathrm{Dental}$ length; 14. $\mathrm{CAL}=$ Carnassial length; $15 . \mathrm{M} 1 \mathrm{~L}=$ Molar length; $16 . \mathrm{CBL}=$ Condylobasal length; $17 . \mathrm{PAL}=\mathrm{Palatinal}$ length; 18. $\mathrm{BBL}=$ Brain basis length; 19. MXT= Maxillary tooth; 20. BRC= Breadth over the canines; $21 . \mathrm{INW}=\mathrm{Incisor}$ width; 22. JUB= Jugal (zygomatic) breadth; 23. FMW= Foramen magnum width; 24. FMH= Foramen magnum high; 25. $\mathrm{ABL}=$ Auditory bulla length and $26 . \mathrm{ABW}=$ Auditory bulla width. 
Brain cavity size (BCS) was calculated as a result of the following multiplication: POL x BCB x CSH (Baranowski et al., 2013). Cranial and mandibular weights were determined to the nearest $0.01 \mathrm{~g}$. Mean values, standard deviations and coefficients of variation for each trait, as well as differences between sexes, were determined and processed statistically with univariate analysis of variance using Statistica v.10 PL computer software package. In addition, the values of the following indices were calculated:

Index $1=$ NAL $x$ 100/CBL

Index $2=$ NCL $\times 100 / C B L$

Index $3=$ JUB $\times 100 / C B L$

Index $4=$ POC $\times 100 /$ IOC

Index $5=\sqrt[3]{\text { Brain cavity size (BCS) }} \times 100 /$ Condylobasal length $(\mathrm{CBL})$

Index $6=$ Mandibular weight $\mathrm{x}$ 100/BCS

Index 7 = Mandibular weight $x$ 100/ MAL

Index $8=\mathrm{BCH}$ x 100/ Mandibular weight

Index $9=$ Mandibular weight $\times 100 /$ Cranial weight

Index $10=\mathrm{BCB} \times 100 / \mathrm{BBL}$
Index $11=\mathrm{CSH} \times 100 / \mathrm{CBL}$

Index $12=$ PAL $\times 100 / \mathrm{BBL}$

Index $13=\mathrm{ABW} \times 100 / \mathrm{ABL}$

Index $14=\mathrm{ABL} \times 100 / \mathrm{BBL}$

Index 15 = FMH x 100/FMW

Index $16=$ FMW $x$ 100/MAB

Index $17=\mathrm{FMH} \times 100 / \mathrm{BCH}$

Index $18=$ DNL $x$ 100/MAL

Index $19=$ CAW $\times 100 / \mathrm{DNL}$

Index $20=\mathrm{CAW} \times 100 / \mathrm{MAL}$

Index $21=$ MAH x 100/MAL

The values of a coefficient describing differences between sexes (i.e. sexual size dimorphism, SSD) were calculated using the following equation (Abramov \& Puzachenko, 2009):

$\mathrm{SSD}=($ mean male - mean female $/$ mean male + mean female) $\mathrm{x} 100$

\section{RESULTS}

Table I. American mink cranial and mandibular weights.

\begin{tabular}{lccccccc}
\hline \multirow{2}{*}{ Trait (g) } & \multirow{2}{*}{ Sex } & \multicolumn{3}{c}{ Brown } & \multicolumn{3}{c}{ Sapphire } \\
\cline { 3 - 7 } & & $\mathbf{X}$ & $\mathbf{S D}$ & $\mathbf{C V}$ & $\mathbf{X}$ & $\mathbf{S D}$ & $\mathbf{C V}$ \\
\hline \multirow{2}{*}{ Carcass } & $\mathrm{M}$ & $1894.86^{* *}$ & 241.44 & 12.74 & $1783.59^{* *}$ & 224.15 & 12.57 \\
& $\mathrm{~F}$ & $1057.59^{* *}$ & 233.94 & 22.12 & $1051.80^{* *}$ & 115.47 & 10.46 \\
Cranium & $\mathrm{M}$ & $12.16^{* * a}$ & 1.55 & 12.06 & $10.52^{* * a}$ & 1.60 & 15.18 \\
& $\mathrm{~F}$ & $8.14^{* *}$ & 1.37 & 16.89 & $7.15^{* *}$ & 0.75 & 10.46 \\
Mandible & $\mathrm{M}$ & $4.72^{* *}$ & 0.55 & 11.61 & $4.45^{* *}$ & 0.79 & 17.87 \\
& $\mathrm{~F}$ & $3.08^{* *}$ & 0.54 & 17.65 & $2.70^{* *}$ & 0.25 & 9.33 \\
\hline
\end{tabular}

Mean values marked in rows with the same lower case letters differ significantly: a or $\mathrm{A}=\mathrm{P} \leq 0.05$; mean values marked in columns with asterisks differ significantly: $* \mathrm{P} \leq 0.05 ; * * \mathrm{P} \leq 0.01 ; \mathrm{SD}=$ standard deviation; $\mathrm{CV}=$ coefficient of variation.

Table II. Biometry of the dorsal surface of American mink cranium.

\begin{tabular}{|c|c|c|c|c|c|c|c|}
\hline \multirow{2}{*}{$\begin{array}{l}\text { Trait } \\
(\mathbf{m m})\end{array}$} & \multirow[b]{2}{*}{ Sex } & \multicolumn{3}{|c|}{ Brown } & \multicolumn{3}{|c|}{ Sapphire } \\
\hline & & $\mathbf{X}$ & SD & $\mathrm{CV}$ & $\mathbf{X}$ & SD & $\mathrm{CV}$ \\
\hline \multirow{3}{*}{ NAL } & M & $17.89 *_{\mathrm{A}}$ & 1.37 & 7.68 & $13.64 \mathrm{~A}$ & 2.37 & 17.40 \\
\hline & $\mathrm{F}$ & $16.71 *_{\mathrm{A}}$ & 1.40 & 8.39 & $12.01 \mathrm{~A}$ & 1.49 & 12.37 \\
\hline & M & $50.31 * *_{\mathrm{A}}$ & 1.68 & 3.33 & $64.59 \mathrm{~A}$ & 9.16 & 14.19 \\
\hline POL & $\mathrm{F}$ & $44.11 * *_{\mathrm{A}}$ & 2.54 & 5.75 & $59.58 \mathrm{~A}$ & 1.47 & 2.46 \\
\hline \multirow[b]{2}{*}{ NCL } & M & $44.03 * *$ & 2.62 & 5.95 & $44.75 * *$ & 5.42 & 12.11 \\
\hline & $\mathrm{F}$ & $38.71 * *$ & 2.43 & 6.28 & $37.67 * *$ & 4.29 & 11.38 \\
\hline \multirow[b]{2}{*}{ IOC } & M & $16.89 * *$ & 0.70 & 4.16 & $16.66^{* *}$ & 1.23 & 7.38 \\
\hline & F & $14.67 * *$ & 0.90 & 6.16 & $14.35 * *$ & 0.39 & 2.75 \\
\hline \multirow[b]{2}{*}{ POC } & M & 13.09 & 0.84 & 6.40 & 12.42 & 1.06 & 8.56 \\
\hline & F & 12.45 & 0.96 & 7.71 & 12.03 & 0.71 & 5.87 \\
\hline \multirow{3}{*}{$\mathrm{BCB}$} & M & $31.03 * *_{\mathrm{A}}$ & 1.60 & 5.16 & $34.97 * *^{\mathrm{A}}$ & 2.03 & 5.80 \\
\hline & $\mathrm{F}$ & $28.41 * *_{\mathrm{A}}$ & 1.00 & 3.51 & $31.86^{* * \mathrm{~A}}$ & 1.20 & 3.7 \\
\hline & M & $39.23 * *$ & 2.19 & 5.58 & $36.93 *$ & 4.35 & 11.79 \\
\hline MAB & $\mathrm{F}$ & $34.12 * *$ & 1.84 & 5.39 & $32.97 *$ & 1.04 & 3.15 \\
\hline
\end{tabular}

Mean values marked in rows with the same lower case letters differ significantly: a or $\mathrm{A}=\mathrm{P} \leq 0.05$; mean values marked in columns with asterisks differ significantly: * $\mathrm{P} \leq 0.05 ; * \mathrm{P} \leq 0.01 ; \mathrm{SD}=$ standard deviation; $\mathrm{CV}=$ coefficient of variation. 
BARANOWSKI, P.; PEZINSKA-KIJAK, K.; FELSKA-BLASZCZYK, L.; ZUK, K.; NOWAK, P.; KOSECKA, J.; OCZERETKO, K.; CHUKWU, P. \& MAZUR, P. An attempt to determine the size of biometric differences in the skull of two colour variants of American mink (Neovison vison). Int. J. Morphol., 32(3):895-901, 2014.

Table III. Biometry of the lateral surface of American mink cranium and mandible.

\begin{tabular}{|c|c|c|c|c|c|c|c|}
\hline \multirow{2}{*}{$\begin{array}{l}\text { Trait } \\
(\mathbf{m m})\end{array}$} & \multirow[b]{2}{*}{ sex } & \multicolumn{3}{|c|}{ Brown } & \multicolumn{3}{|c|}{ Sapphire } \\
\hline & & $\mathbf{X}$ & SD & CV & $\mathbf{X}$ & SD & $\mathrm{CV}$ \\
\hline \multirow[b]{2}{*}{ FSH } & M & $22.05 * *_{\mathrm{a}}$ & 1.95 & 8.75 & $24.14 * *_{\mathrm{a}}$ & 2.17 & 9.11 \\
\hline & $\mathrm{F}$ & $19.04 * *_{\mathrm{A}}$ & 1.94 & 10.02 & $21.18 * *_{\mathrm{A}}$ & 1.83 & 8.20 \\
\hline \multirow[b]{2}{*}{$\mathrm{BCH}$} & M & $39.34 * *_{\mathrm{A}}$ & 4.77 & 12.12 & $21.61 * *_{\mathrm{A}}$ & 1.10 & 5.11 \\
\hline & $\mathrm{F}$ & $33.48 * *_{\mathrm{A}}$ & 3.88 & 11.59 & $19.32 * *_{\mathrm{A}}$ & 0.86 & 4.45 \\
\hline \multirow[b]{2}{*}{$\mathrm{CSH}$} & M & $40.43 *^{\mathrm{A}}$ & 1.60 & 3.96 & $27.36 * *_{\mathrm{A}}$ & 3.23 & 11.81 \\
\hline & F & $34.32 * *_{\mathrm{A}}$ & 4.00 & 11.66 & $23.29 * *_{\mathrm{A}}$ & 0.72 & 3.10 \\
\hline \multirow[b]{2}{*}{ MAH } & M & $21.58 * *$ & 1.22 & 5.66 & $20.90 * *$ & 2.20 & 10.54 \\
\hline & $\mathrm{F}$ & $17.99 * *$ & 1.39 & 7.74 & $18.32 * *$ & 0.98 & 5.32 \\
\hline \multirow[b]{2}{*}{ MAL } & M & $45.78 * *$ & 1.22 & 2.66 & $45.80 * *$ & 4.02 & 8.77 \\
\hline & $\mathrm{F}$ & $39.62 * *$ & 1.95 & 4.92 & $40.06 * *$ & 0.98 & 2.45 \\
\hline \multirow[b]{2}{*}{ DNL } & M & $27.55 * *_{a}$ & 0.99 & 3.61 & $26.11 * *_{\mathrm{a}}$ & 1.43 & 5.50 \\
\hline & $\mathrm{F}$ & $25.00 * *_{\mathrm{a}}$ & 1.38 & 5.53 & $23.77 * *_{\mathrm{a}}$ & 0.38 & 1.62 \\
\hline \multirow[b]{2}{*}{ CAL } & M & $7.70^{*}$ & 0.58 & 7.54 & $7.75^{*}$ & 0.46 & 5.95 \\
\hline & F & $7.25 *$ & 0.47 & 6.43 & $7.26^{*}$ & 0.26 & 3.57 \\
\hline \multirow[b]{2}{*}{ M1L } & M & $7.67 * *$ & 0.52 & 6.74 & $7.72 * *$ & 0.50 & 6.44 \\
\hline & $\mathrm{F}$ & $7.18 * *$ & 0.42 & 5.85 & $7.06^{* *}$ & 0.33 & 4.61 \\
\hline
\end{tabular}

Mean values marked in rows with the same lower case letters differ significantly: a or $\mathrm{A}=\mathrm{P} \leq 0.05$; mean values marked in columns with asterisks differ significantly: * $\mathrm{P} \leq 0.05 ; * * \mathrm{P} \leq 0.01 ; \mathrm{SD}=$ standard deviation; $\mathrm{CV}=$ coefficient of variation.

Comparison of the values of basic morphological traits of both mink groups showed no statistically significant inter-population differences within sexes for body and mandibular weights. On the other hand, the cranial weight in the Brown variant minks was significantly higher $(\mathrm{P} \leq 0.05)$ than that in the Sapphire ones (Table I). Dimorphic differences were statistically significant for all traits - except postorbital cranial breadth (POC), both for the skulls of the Brown mink variant and those of the Sapphire one, and nasal length (NAL), postorbital length (POL) and foramen magnum width and height (FMW and FMH); the relative values of these differences are presented in Table $\mathrm{V}$.

Table IV. Biometry of the skull base of American mink cranium.

\begin{tabular}{|c|c|c|c|c|c|c|c|}
\hline \multirow{2}{*}{$\begin{array}{l}\text { Trait } \\
(\mathbf{m m})\end{array}$} & \multirow[b]{2}{*}{ Sex } & \multicolumn{3}{|c|}{ Brown } & \multicolumn{3}{|c|}{ Sapphire } \\
\hline & & $\mathbf{X}$ & SD & $\mathrm{CV}$ & $\mathbf{X}$ & SD & $\mathrm{CV}$ \\
\hline \multirow[b]{2}{*}{ CBL } & $\mathrm{M}$ & $74.85 * *$ & 1.47 & 1.96 & $74.56^{* *}$ & 3.54 & 4.75 \\
\hline & $\mathrm{F}$ & $67.21^{* *}$ & 2.85 & 4.23 & $65.87 * *$ & 1.71 & 2.60 \\
\hline \multirow[b]{2}{*}{ PAL } & M & $32.32 * *^{\mathrm{a}}$ & 1.43 & 4.43 & $34.19 * *^{\mathrm{a}}$ & 1.75 & 5.14 \\
\hline & F & $28.60 * * \mathrm{~A}$ & 1.30 & 4.56 & $31.16^{* * \mathrm{~A}}$ & 1.07 & 3.43 \\
\hline \multirow{3}{*}{ BBL } & M & $35.33 * *$ & 1.56 & 4.42 & $35.61 * *$ & 1.48 & 4.15 \\
\hline & $\mathrm{F}$ & $31.97 * *$ & 1.35 & 4.23 & $31.11^{* *}$ & 0.99 & 3.19 \\
\hline & M & $23.21^{* *}$ & 1.04 & 4.49 & $23.29 * *$ & 0.72 & 3.11 \\
\hline MXT & $\mathrm{F}$ & $21.24 * *$ & 0.87 & 4.10 & $20.87 * *$ & 0.41 & 1.98 \\
\hline \multirow{3}{*}{$\mathrm{BRC}$} & M & $15.31 * *$ & 0.83 & 5.42 & $16.11^{* *}$ & 0.85 & 5.30 \\
\hline & $\mathrm{F}$ & $13.54 * *$ & 0.75 & 5.51 & $13.65^{* *}$ & 0.54 & 3.99 \\
\hline & M & $6.53 * * \mathrm{a}$ & 0.53 & 8.28 & $7.07 * *_{\mathrm{a}}$ & 0.38 & 5.42 \\
\hline \multirow[t]{2}{*}{ INW } & $\mathrm{F}$ & $6.02 * * \mathrm{a}$ & 0.40 & 6.62 & $6.42 * *_{\mathrm{a}}$ & 0.29 & 4.47 \\
\hline & M & $42.58 * *$ & 1.88 & 4.42 & $42.14 * *$ & 1.93 & 4.59 \\
\hline JUB & $\mathrm{F}$ & $36.76^{* *}$ & 1.54 & 4.12 & $36.07 * *$ & 1.16 & 3.23 \\
\hline \multirow{3}{*}{ FMW } & M & $10.28 * *$ & 1.00 & 9.68 & 10.94 & 0.50 & 4.58 \\
\hline & $\mathrm{F}$ & $9.39 * *$ & 0.80 & 8.48 & 9.97 & 0.39 & 3.87 \\
\hline & M & $5.19^{\mathrm{a}}$ & 0.81 & 15.54 & $5.72^{\mathrm{a}}$ & 0.38 & 6.61 \\
\hline \multirow[t]{2}{*}{ FMH } & $\mathrm{F}$ & $5.18^{\mathrm{a}}$ & 0.93 & 18.01 & $5.69^{\mathrm{a}}$ & 0.29 & 5.28 \\
\hline & M & $18.30 * *^{\mathrm{a}}$ & 0.88 & 4.80 & $19.44 * *^{\mathrm{a}}$ & 0.87 & 4.48 \\
\hline $\mathrm{ABL}$ & $\mathrm{F}$ & $17.34 * *$ & 0.75 & 4.34 & $17.05^{* *}$ & 0.63 & 3.71 \\
\hline \multirow[b]{2}{*}{ ABW } & M & $14.59 * *^{\mathrm{a}}$ & 1.11 & 7.58 & $13.33^{* * a}$ & 1.04 & 7.78 \\
\hline & F & $13.23 * * \mathrm{~A}$ & 0.76 & 5.74 & $11.71 * * \mathrm{~A}$ & 0.47 & 4.04 \\
\hline
\end{tabular}

Mean values marked in rows with the same lower case letters differ significantly: a or $A=P \leq 0.05$; mean values marked in columns with asterisks differ significantly: $* \mathrm{P} \leq 0.05 ; * * \mathrm{P} \leq 0.01 ; \mathrm{SD}=$ standard deviation; $\mathrm{CV}=$ coefficient of variation. 
Table V. The values of size sexual dimorphism (SSD) for morphological parameters and biometric traits of the crania and mandibles of two American mink colour variants.

\begin{tabular}{ccc}
\hline Trait & Brown (Pastel) & Sapphire (Cerulean) \\
\hline \multicolumn{3}{c}{ Morphological parameters } \\
Carcass & 28.36 & 25.81 \\
Cranium & 19.80 & 19.07 \\
Mandible & 21.10 & 24.47 \\
\multicolumn{3}{c}{ Dorsal surface of cranium } \\
NAL & BRC \\
POL & 6.57 & 6.13 \\
NCL & 6.43 & 4.03 \\
IOC & 7.03 & 8.59 \\
POC & 2.50 & 7.44 \\
BCB & 4.41 & 1.59 \\
MAB & 6.97 & 4.65 \\
& 7.77 & 5.66 \\
FSH & 8.05 & 3.36 \\
BCH & 8.17 & 2.44 \\
CSH & 9.07 & 8.03 \\
MAH & 7.21 & 6.57 \\
MAL & 4.85 & 6.66 \\
DNL & 3.01 & 4.69 \\
CAL & 3.29 & 3.26 \\
M1L & Skull base & 4.46 \\
& 5.38 & 6.86 \\
CBL & 6.11 & 6.19 \\
PAL & 4.99 & 1.65 \\
BBL & 4.43 & 6.74 \\
MXT & 6.13 & 6.82 \\
BRC & 4.41 & 6.53 \\
INW & 7.33 & \\
JUB & 4.52 & \\
FMW & 0.09 & \\
FMH & 2.69 & \\
ABL & 4.89 & \\
ABW & & \\
\hline
\end{tabular}

Mean values marked in rows with the same lower case letters differ significantly: a or $\mathrm{A}=\mathrm{P} \leq 0.05$; mean values marked in columns with asterisks differ significantly: $* \mathrm{P} \leq 0.05 ; * * \mathrm{P} \leq 0.01 ; \mathrm{SD}=$ standard deviation; $\mathrm{CV}=$ coefficient of variation

The male and female skulls of the Brown mink variant were characterized by significantly longer $(\mathrm{P} \leq 0.01)$ nasal bone (NAL) but by significantly smaller $(\mathrm{P} \leq 0.01)$ postorbital length $(\mathrm{POL})$ and smaller $(\mathrm{P} \leq 0.01)$ brain case breadth $(\mathrm{BCB})$ than those of the Sapphire one. The skulls of the Brown mink variant were lower in the frontal part (FSH) than those of the Sapphire one, the brain case height of which in both dimensions (BCH and $\mathrm{CSH}$ ) significantly exceeded the skulls of the Brown mink variant. The dental length (DNL) of the Brown variant minks was significantly higher $(\mathrm{P} \leq 0.01)$ when compared to the value of that trait in the Sapphire ones.
Table VI. The values of cranial and mandibular indices for two American mink colour variants.

\begin{tabular}{|c|c|c|c|}
\hline Index & Sex & Brown & Sapphire \\
\hline \multirow[b]{2}{*}{ BCS } & M & $61.66 * *_{\mathrm{a}}$ & $49.06 * *_{a}$ \\
\hline & $\mathrm{F}$ & $42.08 * *_{\mathrm{a}}$ & $36.72 * *_{\mathrm{a}}$ \\
\hline \multirow{2}{*}{$\begin{array}{l}\sqrt[3]{ } \sqrt{\text { Brain cavity }} \\
\text { size }(B C S)\end{array}$} & M & $3.94 * *_{\mathrm{a}}$ & $3.64 * * a$ \\
\hline & $\mathrm{F}$ & $3.47 * *$ & $3.32 * *$ \\
\hline \multirow[b]{2}{*}{1} & M & $24.16 \mathrm{~A}$ & $18.28 \mathrm{~A}$ \\
\hline & $\mathrm{F}$ & $24.89_{\mathrm{A}}$ & $18.21 \mathrm{~A}$ \\
\hline \multirow[b]{2}{*}{2} & M & 59.46 & 59.92 \\
\hline & $\mathrm{F}$ & 57.59 & 57.20 \\
\hline \multirow[b]{2}{*}{3} & M & 56.50 & $56.54 *$ \\
\hline & $\mathrm{F}$ & 56.70 & $54.76^{*}$ \\
\hline \multirow[b]{2}{*}{4} & M & $77.50 * *$ & $74.86^{*}$ \\
\hline & $\mathrm{F}$ & $85.01 * *$ & $83.94 *$ \\
\hline \multirow[b]{2}{*}{5} & $\mathrm{M}$ & $5.32^{\mathrm{a}}$ & $4.89^{\mathrm{a}}$ \\
\hline & $\mathrm{F}$ & $5.17^{\mathrm{a}}$ & $5.04^{\mathrm{a}}$ \\
\hline \multirow[b]{2}{*}{6} & M & 7.90 & $9.25^{*}$ \\
\hline & $\mathrm{F}$ & 7.47 & $7.35^{*}$ \\
\hline \multirow[b]{2}{*}{7} & M & $10.30 * *$ & $9.62 * *$ \\
\hline & $\mathrm{F}$ & $7.80 * *_{\mathrm{a}}$ & $6.76 * *_{\mathrm{a}}$ \\
\hline \multirow[b]{2}{*}{8} & M & $182.30^{\mathrm{A}}$ & $104.46 \mathrm{~A}$ \\
\hline & $\mathrm{F}$ & $187.27^{\mathrm{A}}$ & $105.69_{\mathrm{A}}$ \\
\hline \multirow[b]{2}{*}{9} & M & 39.13 & $42.15 * *$ \\
\hline & $\mathrm{F}$ & 37.95 & $37.83 * *$ \\
\hline \multirow{3}{*}{10} & M & $88.01 \mathrm{~A}$ & $98.30 \mathrm{~A}$ \\
\hline & $\mathrm{F}$ & $88.96 \mathrm{~A}$ & $102.45 \mathrm{~A}$ \\
\hline & M & $53.39 \mathrm{~A}$ & $36.72 \mathrm{~A}$ \\
\hline \multirow[t]{2}{*}{11} & $\mathrm{~F}$ & $51.14 \mathrm{~A}$ & $35.36 \mathrm{~A}$ \\
\hline & M & $91.54 \mathrm{a}$ & $96.01 \mathrm{a}$ \\
\hline \multirow[t]{2}{*}{12} & $\mathrm{~F}$ & $89.51 \mathrm{a}$ & $151.61 \mathrm{a}$ \\
\hline & M & $79.74 \mathrm{~A}$ & $68.55 \mathrm{~A}$ \\
\hline \multirow[t]{2}{*}{13} & $\mathrm{~F}$ & $76.40 \mathrm{~A}$ & $68.53 \mathrm{~A}$ \\
\hline & M & $51.88 * *_{\mathrm{a}}$ & $54.60 \mathrm{a}$ \\
\hline 14 & $\mathrm{~F}$ & $54.29 * *$ & 54.85 \\
\hline \multirow{3}{*}{15} & $\mathrm{M}$ & 49.38 & 52.42 \\
\hline & $\mathrm{F}$ & 54.27 & 54.25 \\
\hline & $\mathrm{M}$ & $26.24 \mathrm{a}$ & $30.05 \mathrm{a}$ \\
\hline \multirow[t]{2}{*}{16} & $\mathrm{~F}$ & $27.67 \mathrm{a}$ & $30.25 \mathrm{a}$ \\
\hline & $\mathrm{M}$ & $13.05 * *^{\mathrm{A}}$ & $26.52 \mathrm{~A}$ \\
\hline 17 & $\mathrm{~F}$ & $15.48 * * \mathrm{~A}$ & $28.01 \mathrm{~A}$ \\
\hline \multirow{3}{*}{18} & M & $60.19 * *_{\mathrm{a}}$ & $57.18 *_{\mathrm{a}}$ \\
\hline & $\mathrm{F}$ & $63.12 * *^{\mathrm{A}}$ & $59.35 *_{\mathrm{A}}$ \\
\hline & $\mathrm{M}$ & 27.98 & 29.70 \\
\hline \multirow[t]{2}{*}{19} & $\mathrm{~F}$ & $29.05 \mathrm{a}$ & $30.53 a$ \\
\hline & M & $16.83^{* *}$ & $16.98 * *$ \\
\hline 20 & $\mathrm{~F}$ & $18.33^{* *}$ & $18.12 * *$ \\
\hline \multirow[b]{2}{*}{21} & M & $47.13^{*}$ & 45.57 \\
\hline & $\mathrm{F}$ & $45.39^{*}$ & 45.73 \\
\hline
\end{tabular}

Mean values marked in rows with the same lower case letters differ significantly: a or $\mathrm{A}=\mathrm{P} \leq 0.05$; mean values marked in columns with asterisks differ significantly: * $\mathrm{P} \leq 0.05 ; * * \mathrm{P} \leq 0.01 ; \mathrm{SD}=$ standard deviation; $\mathrm{CV}=$ coefficient of variation. 
Statistical analysis of the values of skull basis traits showed that the skulls of the Sapphire mink variant were characterized by significantly $(\mathrm{P} \leq 0.05$ and $\mathrm{P} \leq 0.01)$ longer palate (PAL) and larger incisor width (INW), foramen magnum width (FMH) and auditory bulla length (ABL), with smaller auditory bulla width (ABW).

The analysis carried out demonstrated that neurocranium of the Sapphire variant minks takes more flattened shape with elevated frontal part. Despite larger length of neurocranium (POL) in the Sapphire variant minks, its capacity (BCS) was significantly smaller $(\mathrm{P} \leq 0.01)$ when compared to that of the Brown variant mink skulls. Analysis of the relative values of skull traits is supplemented by calculated cranial and mandibular indices (Table VI).

\section{DISCUSSION}

The study conducted included the skulls of animals in their first year after birth, fully developed somatically (Kruska, 1979) and free from invasive parasitic diseases infestations being able to deform certain skull traits (Dubnitskii, 1956). It demonstrated that sexual dimorphism - despite intensive selection conducted in a mink farm aiming, among others, at standardization of a large number of animals for the size of pelts being obtained - was well pronounced almost in all skull traits. The male skulls were longer, broader and higher than the female ones. This finding confirms the same earlier information (Jakubowski et al., 2008). However, the data on bigger postorbital part of female skull, as observed in wild minks, were not confirmed but the palatinal length was similarly larger in male minks, as observed in wild population (Wiig, 1986).

Confronting the results of morphometric analysis of the crania and mandibles of standard Brown (Pastel) variant minks with those of double recessive mutant Sapphire (Cerulean) one indicates the phenomenon of paedomorphy, being already described in farm animals, may have occurred. Typical paedomorphic traits are smaller viscerocranium length and neurocranium capacity. Both of these conditions are met by the skulls of the Sapphire (Cerulean) variant minks, the males of which had smaller cranium capacity by more than $18 \%$, while the females by more than $12 \%$, than those of the Brown variant minks. Also cranial indices, being used in population biology, document quite clearly the occurring relationships. This indicates inability to objectively evaluate the skull based only on the condylobasal length (CBL) as it did not differentiate the skulls of both colour mink variants, like wild mink populations from two different geographical regions (Kruska \& Sidorovich). Decrease in the size of respective skull areas, in particular of its viscerocranium in the Sapphire mink variant, may result from advanced selection and use of mutation effect in this species breeding. It should be remembered that mink colour is affected by 31 gene pairs acting independently of each other, among which dominant and recessive genes can be found. Mink colour variants, coloured differently than the standard one, were formed through mutation of one locus or as a result of cross-breeding of mutant variants between each other. In literature, attention has been paid to the effect of farm mink colour on not just skull size but its shape (Lynch \& Hayden, 1995). Variation in the skull shape in domestic and farm animals is a well-known phenomenon progressing with age (Onar \& Günes, 2003) but also as a result of rearing in captivity (Baranowski et al., 2014).

The study performed showed that production of new colour variants, being mink colour mutations, applied in fur farms may be a source of variation for skull morphological traits and relationships between respective elements of viscerocranium and neurocranium.

BARANOWSKI, P.; PEZINSKA-KIJAK, K.; FELSKABLASZCZYK, L.; ZUK, K.; NOWAK, P.; KOSECKA, J.; OCZERETKO, K.; CHUKWU, P. \& MAZUR, P. Un intento de determinar la magnitud de las diferencias biométricas del cráneo de dos Variedades de Color del Visón Americano (Neovison vison). Int. J. Morphol., 32(3):895-901, 2014.

RESUMEN: El objetivo de este estudio fue responder a la pregunta de si la producción de nuevas variedades de color del visón americano en granjas mediante mutaciones puede causar cambios en la morfología del esqueleto de la cabeza y en las relaciones mutuas de los elementos óseos que lo construyen. Los estudios se realizaron en 56 machos y hembras de ocho meses de dos variedades de color del visón americano (bronce estándar y zafiro por mutación) derivados de la misma granja. Se determinaron valores medios, DE y coeficiente de variación para peso corporal, del cráneo y la mandíbula, además de 7 rasgos de la superficie del dorso, 8 de la superficie lateral y 11 características de la base del cráneo. Fueron calculados los valores de 24 índices craneales y mandibulares, junto al valor de la magnitud del dimorfismo sexual, i.e. un coeficiente de las diferencias entre los sexos. Se demostró que las variedades mutantes de color del visón pueden ser fuente significativa $(p \leq 0,05$ y $p \leq 0,01)$ de variación para algunas características morfológicas del esqueleto de la cabeza y relaciones entre elementos óseos del víscero y neurocráneo.

PALABRAS CLAVE: Biometría; Visón americano; Viscerocráneo; Neurocráneo. 


\section{REFERENCES}

Abramov, A. V. \& Puzachenko, A. Y. Spatial variation of sexual dimorphism in the Siberian weasel Mustela sibirica (Mustelidae, Carnivora). Russian J. Theriol. 8(1):17-28, 2009.

Baranowski, P.; Wróblewska, M.; Nowak, P. \& Pezinska, K. Biometry of the Skull of Wild and Farm Long-tailed Chinchilla (Chinchilla laniger, Molina, 1782). Int. J. Morphol., 31(3):1003-11, 2013.

Baranowski, P.; Wroblewska, M. \& Pezinska-Kijak K. Shape variability in the Skull of Long-tailed Chinchilla (Chinchilla laniger, Molina 1782). Part 1. Cranial angles. Folia Pomer. Univ. Technol. Stetin., Agric., Aliment., Pisc., Zootech. 309 (29): 5-14, 2014.

Dubnitskii, A. A. A study of the development of the Nematode Skrjabingylus nasicola, a parasite of the frontal sinuses of Mustelids. Karakulev. Zverov., 1:59-61, 1956.

Felska-Blaszczyk, L.; Najmowicz, M.; Sulik, M. \& Blaszczyk, P. Wybrane parametry rozrodu norek (Neovison vison) roznych odmian barwnych w aspekcie dugosci ciazy. Zesz. Nauk. Prz. Hod., 4(4):147-57, 2008.

Felska-Blaszczyk, L.; Sulik, M. \& Dobosz, M. Wpyw wieku i odmiany barwnej na wskazniki Rozrodu norek (Neovison vison). Acta Sci. Pol., Zootechnica, 9(3):19-30, 2010.

Jakubowski, H.; Komosa, M. \& Fra ckowiak, H. Allometric analysis of cranial parameters of American mink, including bones of masticatory apparatus. Electron. J. Pol. Agric. Univ., 11(3):2, 2008.

Kidd, A. G.; Bowman, J.; Lesbarrères, D. \& Schulte-Hostedde, A. I. Hybridization between escaped domestic and wild American mink (Neovison vison). Mol. Ecol., 18(6):1175-86, 2009.

Kruska, D. Vergleichende Untersuchungen an den Schädeln von Subadulten und Adulten Farmnerzen, Mustela vison f. dom. (Mustelidae; Carnivora). Zeitschrift für Säugetierkunde, 68:257-76, 1979.

Kruska, D. \& Schreiber, A. Comparative morphometrical and biochemical-genetic investigations in wild and ranch mink (Mustela vison: Carnivora: Mammalia). Acta Theriol., 44(4):377-92, 1999.

Kruska, D. C. T. \& Sidorovich, V. E. Comparative allometric skull morphometrics in mink (Mustela vison Schreber, 1777) of Canadian and Belarus origin; taxonomic status. Mamm. Biol., 68(5):257-76, 2003.

Liu, Z.; Ning, F.; Du, Z.; Yang, C.; Fu, J.; Wang, X. \& Bai, X. Modelling growth of five different colour types of mink. $S$. Afr. J. Anim. Sci., 41(2):116-25, 2011.
Lynch, J. M. \& Hayden, T. J. Genetic influences on cranial form: variation among ranch and feral American mink Mustela vison (Mammalia: Mustelidae). Biol. J. Linn. Soc., 55(4):293-307, 1995.

Onar, V. \& Günes, , H. On the variability of skull shape in German shepherd (Alsatian) puppies. Anat. Rec. A Discov. Mol. Cell. Evol. Biol., 272(1):460-6, 2003.

O'Regan, H. J. \& Kitchener, A. C. The effects of captivity on the morphology of captive, domesticated and feral mammals. Mamm. Rev., 35(3-4):215-30, 2005.

Slaska, B.; Rozempolska-Rucin’ska, I. \& Jez ewska-Witkowska, G. Variation in some reproductive traits of mink (Neovison vison) according to their coat colour. Ann. Anim. Sci., 9(3):28797, 2009.

Shackelford, E. M. American mink. In: Mason, I. L.(Ed.). Evolution of Domesticated Animals. London, Longman, 1984. pp.22934 ,

Sidorovich, V. \& MacDonald, D. W. Density dynamics and changes in habitat use by the European mink and other native mustelids in connection with the American mink expansion in Belarus. Neth. J. Zool., 51(1):107-26, 2001.

Sundqvist, C.; Amador, A. G. \& Bartke, A. Reproduction and fertility in the mink (Mustela vison). J. Reprod. Fert., 85(2):413-41, 1989.

Tamlin, A. L.; Bowman, J. \& Hackett, D. F. Separating wild from domestic American mink Neovison vison based on skull morphometric. Wildl. Biol., 15(3):266-77, 2009.

Wiig, Ø. Sexual dimorphism in the skull of minks Mustela vison, badgers Meles meles and otters Lutra lutra. Zool. J. Linn. Soc., 87(2):163-79, 1986.

Zalewski, A. \& Bartoszewicz, M. Phenotypic variation of an alien species in a new environment: the body size and diet of American mink over time and at local and continental scales. Biol. J. Linn. Soc., 105(3):681-93, 2012.

\section{Correspondence to:}

Prof. Piotr Baranowski, PhD, DSc

Department of Animal Anatomy

Faculty of Biotechnology and Animal Husbandry

Western Pomeranian University of Technology in Szczecin 14 Doktora Judyma St.

71-466 Szczecin

POLAND

\section{Email: Piotr.Baranowski@zut.edu.pl}

Received: 27-02-2014 Accepted: 23-05-2014 